\title{
Performance Appraisal and its Effect on Employees' Productivity in Charitable Organizations
}

\section{John Nkeobuna Nnah Ugoani}

Associate Professor, Department of Management Sciences College of Management and Social Sciences, Rhema University, Aba, Nigeria

Email: drjohnugoani@yahoo.com

\author{
Article History \\ Received: November 5, 2020 \\ Revised: December 13, 2020 \\ Accepted: December 23, 2020 \\ Published: December 27, 2020 \\ Copyright (C) 2020 ARPG \& \\ Author \\ This work is licensed under the \\ Creative Commons Attribution \\ International \\ (c) (1) CC BY: Creative \\ Commons Attribution License \\ 4.0
}

\begin{abstract}
Although performance appraisal is concerned with the evaluation of workers job performance, it at the same time serves to highlight the specific objectives of an organization. As the employee is being evaluated the organization is also evaluating itself by comparing objectives and standards of performance, reviews the whole appraisal framework and design as well as organizational values and culture. Performance appraisal is a veritable tool for organizations to evaluate and increase the quality of education and training of their workforce with a view to developing lifelong learning patterns and strategies to sustain productivity throughout longer working periods. Motivation as it relates to employee productivity is often behind the drive for performance and self-actualization, and provides opportunities for higher productivity. Productivity is an important measure of goal achievement, because getting more done with less resources increases organizational profitability. Using the exploratory research design and 109 participants the result of the study indicates strong positive correlation between performance appraisal and employee productivity. It suggests that the issue of performance appraisal in charitable organizations should be addressed. In view of the result of the study, the paper recommends that performance appraisal should carefully review employee's strengths and weaknesses against requirements for possible future higher responsibilities.
\end{abstract}

Keywords: Organizational behaviour modification; Privately-owned-small-enterprises; Management by objectives; Employee motivation; Performance feedback; Subjective appraisals; Behaviourism.

\section{Introduction}

Determining how good a worker is performing on the job and communicating such information is important for improved productivity. Both public and private organizations use the performance appraisal mechanism to weigh both themselves and their employees. According to Mathis and Jackson (1994) after an employee has been selected for a job, trained to do it, and worked on it for a period of time, his or her performance should be reviewed. Therefore, performance appraisal is the process of evaluating how well employees do their jobs as compared with a set of standards and then taking necessary action so as to enable them make adjustments on the job. In practice, performance appraisal is called different names by different establishments to suit their own unique purpose. The public sector in Nigeria calls it APER -Annual Performance Review. Other organizations use such names as employee rating, employee evaluation, performance review, performance evaluation, among others. Despite the importance of performance appraisal it does not seem to be a major activity in some charitable organizations. Such lackadaisical attitude might have grown out of the feeling that not all performance appraisals are objective. For such reason, discussing appraisal rating with employees may not be necessary. In practical terms, it may be difficult to differentiate among employees if good performance data are absent. There are various types of performance appraisals, which play different roles, and also have different uses in organizations. At the general level, performance appraisal involves the evaluation of an employee's progress or lack of it on the job, and measured in terms of job effectiveness, or productivity. Measuring employee productivity and cost is important because employee expense represents a major component of overall costs. Employee productivity is very important to top management because it is also a central measure of general management effectiveness. Performance appraisal therefore, involves the identification, measurement, and management of employees' output in organizations. Effective performance appraisal helps management in finding ways of training and motivating employees so as to retain the best available talents and to improve organizational performance. In the absence of this, the most capable employees may decide to leave an organization, where incentive levels are low, leading to high labour turnover that often has negative effect on productivity. Productivity is a measure of output per employee and means the effective use of organizational resources. The motivational aspect of performance appraisal is central to employee 
productivity because motivation is a key factor in many aspects of work life. Not only can it influence quality and productivity, it also contributes to enhancing conducive work environment. People work for a variety of reasons, and although compensation is often the leading perspective, it is not always the only reason. Other measures include job design, socialization, self-actualization, status, the physiological aspects of work and a sense of purpose and accomplishment. Performance appraisal can reveal the need for these, and in turn help management to develop a motivational mechanism that encourages employees to respond in positive ways to the achievement of organizational objectives. However, appraisals to encourage employee performance is hardly fully done in most charitable organizations like churches, mosques and even their agencies like missionary hospitals and schools. In Nigeria, for example, there is huge mushrooming of non-for-profit entities as charitable organizations (COs) that employ a sizeable number of people who are not developed to their fullest potential. A survey of some of these organizations showed that the level of employee motivation is low which explains poor work attitudes. There are the issues of poor job design, weak lines of authority, zero training and development programmes, as well as least opportunities for promotion due often to lack of established performance appraisal system or human resource management policy (Ugoani, 2016). When employees are not appraised, feedback is denied and they may not readily make adjustments that would lead to improved productivity (Anseel et al., 2015; Bernichon et al., 2003).

\subsection{Research Problem}

To appraise effectively, managers must spot problems, but management is required to provide constructive feedback, and take proper corrective actions to improve employee productivity. Unfortunately, management often finds it extremely difficult to make appraisers' to untangle individual contributions from those of the work team while avoiding judgments based on a personality bias. Issues such as being a strict or lenient appraiser, having likes and dislikes, as well as having a political agenda make a mess of the appraisal system and frequently lead to demotivation and low employee productivity. Another challenge of performance appraisal is that most organizations conduct appraisals only once a year and only a few others do so either half-yearly or quarterly, in such cases, they are unable to capture the real employee performance because of time lag and other inconsistencies. Almost always, on yearly appraisals, what is done is based on the appraisers' subjective judgment rather than based on objective indicators of performance. These inadequacies have made many people to think that appraisals are full of errors and useless in appointments and promotions. However, much of the previous work on performance appraisal and employee productivity focus on government and the organized private sector (OPS). For example, Mwema and Gachunga (2014) focused on performance appraisal and employee productivity in World Health Organization (WHO) where performance appraisal is probably in effective use, and Hernandez (2002) was concerned with local government performance measurement. To some extent, therefore, there is no known work in recent time focusing on performance appraisal and employee productivity in COs. This work therefore, seeks to draw attention to this important area so that attempts will be made to fill the knowledge gap through subsequent researches.

\subsection{Research Objective}

This study was designed to explore the relationship between performance appraisal and employee productivity.

\subsection{Research Significance}

Performance appraisal is a critical management function which helps significantly in boosting employee morale and resulting to improved employee productivity. The result of the study will be of immense benefit to management practitioners, scholars, policy-makers, students and the public who will increase their understanding of the concept and applicability of this concept in various workplace situations.

\subsection{Research Questions}
i. Is it true that performance appraisal helps in compensation management?
ii. Can you say that feedback is part of the performance appraisal process?
iii. Does performance appraisal contribute to management decision-making?
iv. Is performance appraisal related to employee motivation?
v. Are you sure that employee productivity is not important to organizational management?
vi. Do you think that employees in charitable organizations are properly appraised?

\subsection{Hypothesis}

To achieve the objective of the study, this hypothesis was formulated and tested at 0.05 level of significance. Ho: There is no relationship between performance appraisal and employee productivity.

Hi: There is a relationship between performance appraisal and employee productivity.

\subsection{Conceptual Framework}

A conceptual framework is the structure of the study and shows the relationships between the major variables and the research problem. It is usually expressed as a model. A model is an abstraction of reality. The variety of models in use in research is enormous, ranging from the simple to the exotic, some are very crude, and others extremely elegant. However, all models have certain common features. They are all decision-making techniques, and for simplification of more complex real-life phenomena. Models ignore the unimportant details so that attention can be concentrated on the most important aspects of a situation thus, increasing the opportunity to understand a problem 
and its solution. This understanding ability leads to theory building (Stevenson, 2002). The model for this study is shown in figure 1 .

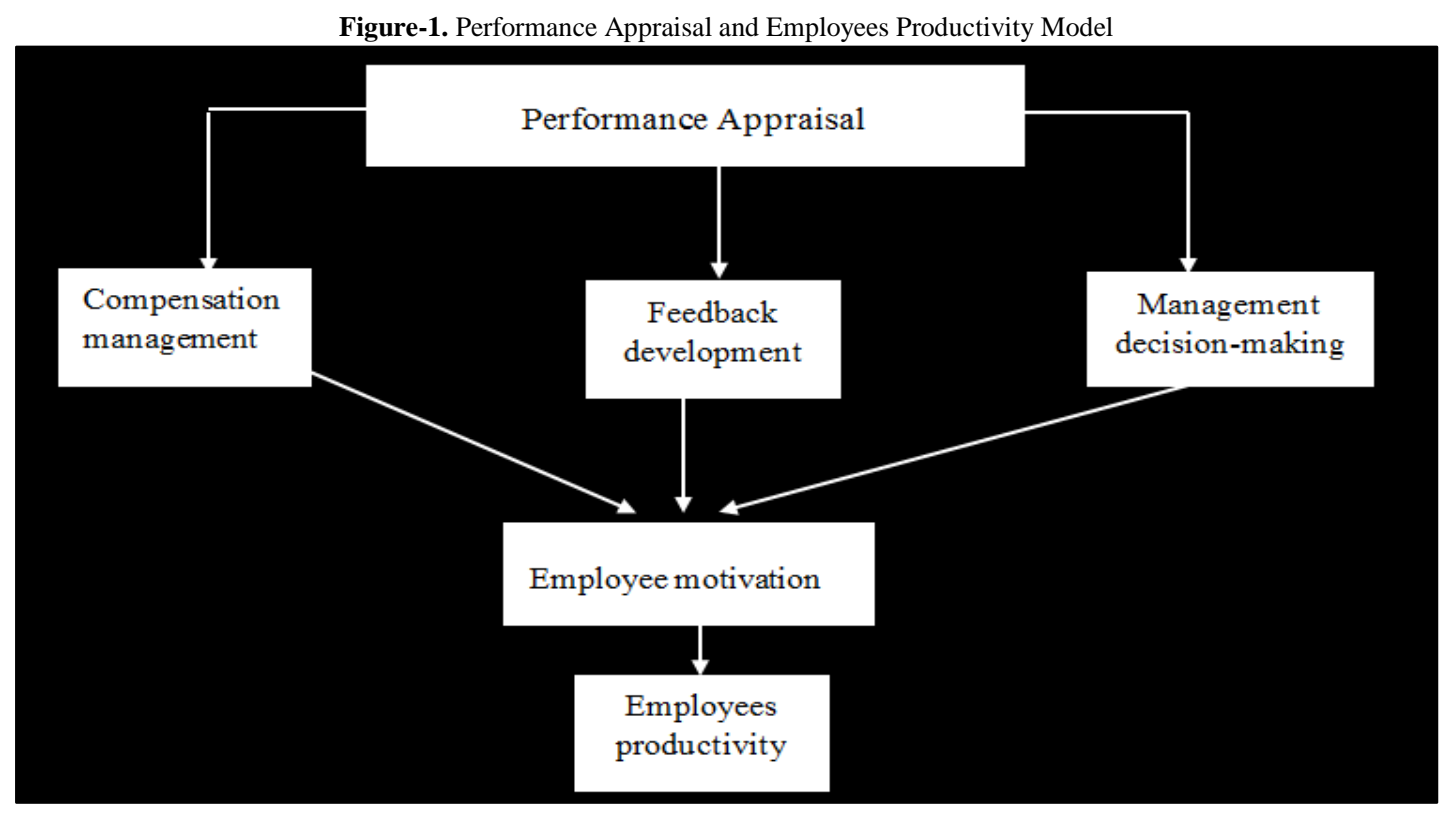

Generally, performance appraisal serves as evaluation and development tool in organizations. Performance appraisal provides a realistic and reliable basis for making crucial management decisions with regard to compensation, employee development, motivation, and promotion, necessary for employee productivity (Zhang and Bartol, 2010). Performance appraisal also provides necessary information for hiring and correct placement, planning and counseling of new employees. As a developmental tool, it equally provides the framework for organizational development by identifying employees with saleable managerial skills, who may be categorized as management materials, for the purposes of higher leadership responsibilities in the organization. As shown in this conceptual model, performance appraisal provides the right motivational tool necessary for higher performance by allowing appraisees' to know how well they have fared in the past through the feedback mechanism (VandeWalle et al., 2000; Whitaker et al., 2007; Zhang et al., 2017). Performance appraisal also enhances employee motivation by ensuring that conditions of employment are so arranged that the immediate needs of employees are satisfied and that conditions in the workplace are such as will provide positive challenges to the employees. This often involves among other things; job enrichment in which the individual's job is made more satisfying through restructuring. It also involves a proper definition of the authority and accountability lines so that the employee knows the framework on which to operate and report. Leisink and Knies (2017), suggest that evaluations help to clarify what is expected of the employee and used to strengthen and improve employee performance; and also help management in refining, validating and establishing an objective basis for personnel decisions (Lindsey, 2005; Longenecker, 1997; Waldersee and Luthans, 1994; Wells, 2002).

\section{Literature Review}

Performance appraisal is an organized, formalized, systematic process of assessing job related strengths and weaknesses of an individual appraisee with the ultimate aim that if he performs well such strengths are encouraged and reinforced and if he performs marginally his work habits can easily be identified and redirected in a manner conducive to the set objectives of the organization. Appraisals are criterion variables that measure job performance of employees at a particular period; a job is a collection of tasks. It is a process whereby an appraiser objectively communicates to an appraisee how he or she is performing the job in order to establish a plan of improvement through training and development, counseling, mentoring, retraining, or other remedial measures. Performance or productivity in this context refers to the degree of accomplishment of the tasks that make the employee's job. According to Udeze (2000) performance appraisal is about evaluating the employee's contribution to the productivity objectives of organizations. The issues of employee productivity and the need to evaluate them have always been a matter of prime concern to management and even to the employee. This is so because the employee needs a feedback on his output in the organization for a particular period. By supervising employee's daily performance on the job, management is in a better position to appraise performance and provide feedback. The evaluation of performance may either be informal or formal. The informal appraisal which is based on the day-today working relationships of an employee and the superior provides an opportunity for the superior to judge the subordinate. This judgement is then communicated through conversation on the job or by on-the-spot examination of a particular task. A formal appraisal is through reporting the superior's observations of an employee's performance to management for necessary action. According to Gomez-Mejia et al. (2004) management has the overriding power over performance appraisal as a measure of achieving superior organizational goals. They opine that appraisal should be just more than a passive activity which criticizes or praises employees for their performance in the preceding year. Rather, appraisal must take a future-oriented view of what employees can do to achieve their potential in the 
organization, in which case, management must provide employees with feedback and coach them to higher levels of productivity. An important feature of an effective evaluation involves conducting appraisal on a regular basis, either every six months or annually. Irregularity in appraisal intervals can affect the employee morale, and also have negative consequences on overall organizational performance (Exley, 2000). Insisting on objective appraisal cannot be overemphasized because it is a motivational tool for employee productivity which contributes to organizational survival. Motivation as it relates to employee productivity is often behind the drive for self-actualization. Selfactualization is a state of self-fulfillment where people feel that they have realized their highest potential in life. It involves being creative and nurturing skills that provide opportunities for success. To a large extent therefore, employee motivation is fundamental as it influences behaviour which leads to productivity. This is critical because the enterprise survives on productivity. Performance assessment focuses on managing the objective, measurable results of a job or work group. Goals might include sales, costs, or services. Goals are specific, difficult, and objective. Productivity is an important measure of success or goal because getting more done with less resources such as; money or people, increases the organization's profits. According to Noe et al. (2004), productivity usually refers to the output of employees, but it can be used more generally as a performance measure. For such to be effective, organizations decide what level of performance it desires. It then sets up a system for tracking these measures and giving employees feedback about their performance in terms of such measures. For example, it is said that the Biblical Adam and Eve evaluation by God marked the first attempt at evaluating worker performance, the only difference being that they were not employees in any form. In the contemporary organization, there are different concepts, roles, uses, types and structures of performance appraisal that aim at employee productivity and overall organizational excellence (Holbrook, 2002).

\subsection{Performance and Potential Appraisals}

This is a unique concept in the performance appraisal mechanism. It emphasizes the importance of identifying the training and development needs of the individual in an organization. It is an obvious improvement of the traditional performance appraisal which at times is misconstrued as a tool for promotions or layoffs. For a meaningful human resource management to be in place, the potential of the individual worker must be differentiated and recognized, irrespective of length of service, age, sex, ethnicity, or religion (Fletcher, 2004).

\subsection{Role of Performance Appraisals}

There are two roles of performance appraisal in organizations that are often seen as potentially conflicting. One role is to measure performance for the purpose of rewarding or differentiating employees. For example, promotions or layoffs might hinge on these ratings, making discussions of them difficult at times. Another role is the development of individual's potential. In this case, the manager is featured more as a counselor than as a judge, and the atmosphere is often different. It is emphasized that performance appraisal helps to bring about employee empowerment teamwork, job satisfaction, and a winning, competitive work spirit (Wilson and Western, 2001).

\subsection{Compensation Administration}

A good performance appraisal system should be seen as the link between the reward an employee hopes to receive and his or her productivity. Such a linkage can be thought of as equal to the individual's productivity $=$ individual's performance appraisal = reward expected. The links must be as strong as possible, if any of them fails, the worker will not get the expected rewards. Equity and fair-play should also take the centre stage in compensation administration so that individual employees' will put in their best at all times. This system of compensation administration is based on the idea that rewards should be given to quality performance or merit instead of seniority. Without undermining the consequences of seniority such as experience, loyalty, the merit system recognizes first and foremost, the productivity and capability of the individual employee. However, the major role of an appraisor is to act as evaluator of employee performance, and usually the focus is on comparison of performance levels of individuals' against set standards and objectives (McGregor, 2010).

\subsection{Feedback for Career Development}

Contrary to what most people think or believe performance appraisal is not only used for promotions and transfers or wage increases. Performance appraisal, even if it is not linked to wage/salary increment, it is a primary source of information and feedback for employees both in areas in which they are doing well and ones where improvement is needed. The import of this is that performance appraisal helps the organization to forecast the future of employees and take appropriate steps to plan for their individual career development. The human capital is the most important aspect of all the factors of production because it is the human being that coordinates, controls, and manages all other factors. For the human being to play these critical roles effectively, he should be highly developed and equipped. The development function of performance appraisal allows for determination of areas in which the employee might wish to grow. Basically, effective performance feedback communicates information that encourages continuous quality performance (London, 1997).

\subsection{Administrative Decisions}

There are many other uses of performance appraisal. Performance appraisal results can safely be classified as administrative decisions. Today, organizational decisions such as promotion, termination, or transfers, are based on performance appraisal results. Most commercial banks in Nigeria, for example, base their annual promotions, 
layoffs, and transfers, on performance appraisal results. Those who score high on a scale of 100 percent are usually rewarded with promotions, and given higher responsibilities while those who score very low are exited from the system. If these decisions are not documented with performance appraisal results they could be successfully challenged in the court of law as lacking basis or equity (Werner and Bolino, 1997).

\subsection{Trait and Behaviour Appraisal}

According to Jones and George (2003), when trait appraisals are employed, managers are concerned with assessment of subordinates on personal characteristics that are relevant to job performance, such as education, skills, capabilities or personality. This means that a workshop employee may be assessed on his ability to operate computerized machines. Also a clerical employee may be evaluated based on his ability to show empathy and/or communication skills. Behaviour appraisals on the other hand assess how employees perform their jobs - the actual actions and behaviours that employees exhibit on the job. For example, in educational institutions such as a high school, the number of classes and students are important, but how students are taught or the methods teachers use to ensure that learning takes place are also important. Therefore, behaviour appraisals have the advantage of providing employees clear information about what they are doing right and wrong and how they can improve their performance. Again, because behaviours are much easier for employees to change than traits, performance feedback from behaviour appraisals is more likely to lead to performance improvements (Anderson, 1993).

\subsection{Result Appraisals}

In certain jobs how employees perform the job is not as important as what they accomplish or the results they obtain. With result appraisals organizations assess performance by the results or the actual output of particular work behaviours. This is output focused to the extent that two employees who have equal sales targets to meet can employ different and distinct approaches. One could be persuasive, by frequent visits and telephone calls to customers, while the other could easily answer customers questions correctly due to his/her expert knowledge and wait for the customers to come back. What will be appraised by the manager is the result achieved by each employee and not necessarily the method used in achieving such a result (Redman et al., 2000).

\subsection{Objective Appraisals}

This is an appraisal that is based on facts and figures and it is usually in numerical terms. Objective appraisals are usually used by organizations while assessing targets. It is easy to check the number of motor cars sold against set targets or standards. If a salesman has the target of selling 1000 cars per annum and he sold 500 it is easy to find out the level of his performance by expressing the number of cars sold as a percentage of the budget, like; 500/1000 $\mathrm{x} 100 / 1=50$ percent. If the point allocated to the number of cars sold is 100 , then this salesman will earn 50 percent in appraisal. This type of appraisal is said to be objective, and enhances motivation. Among the most effective ways to improve employee productivity are high levels of ability and motivation. When employees have high levels of ability and motivation, they perform at or above standards. According to Heller (1998) appraising objectively and effectively provides a good opportunity to assess employees motivation levels. He insists that to motivate well starts by assessing employees objectively.

\subsection{Subjective Appraisals}

An appraisal is said to be subjective when it is based on appraiser's perceptions of traits, behaviours and or results. Subjective appraisals are usually unreliable and misleading because they are based on the apperaser's perceptions. In a situation where the manager or the appraiser does not like an employee the tendency is high, due to human nature, that he will be biased in appraising such an employee. And when this happens, the super-ordinate organization will be misled into taking decisions that it would not otherwise have taken if the employee was objectively appraised (Milkovich and Boudreau, 1997).

\subsection{0-Degree Performance Appraisal}

A 360 - Degree appraisal is performance appraisal by peers, subordinates, superiors and sometimes clients who are in a position to evaluate a manager's performance. This is done to improve motivation and performance. Some organizations include 360 Degree appraisal and feedback in their performance management system especially for managers. In a 360-Degree appraisal, managers' performance is appraised by a variety of people, beginning with the manager's self-appraisal, and includes peers or co-workers, subordinates, superiors and some times, even customers. It has been observed in practice that peers often are very knowledgeable about performance but usually may be reluctant to provide an accurate and negative appraisal of a co-worker they like or a positive appraisal of the person they hate. This natural phenomenon has also tended to render peer appraisal useless. Besides, whenever peers, subordinates or someone else evaluates an employee's performance, the manager must ensure that the appraisers' are truly knowledgeable about the performance dimensions being used. However, these challenges of 360-Degree performance appraisal and feedback do not in any way mean that they are entirely useless (Rowe, 1995). 360-Degree feedback helps in building leadership skills, people development, customer relationships, task knowledge, as well as innovation and creativity (Goodge and Watts, 2000; Huet-Cox et al., 1999). 


\subsection{Organizational Behaviour Modification (OBM)}

Another important performance appraisal approach is organizational behaviour modification (OBM) which builds directly on a branch of psychology known as behaviourism. This perspective holds that individuals' future behaviour is determined by their past experience, specifically, the ways in which past behaviour has been reinforced. People tend to repeat behaviours that have been rewarded in the past, as a basis for current behaviour. Providing feedback and reinforcement can obviously modify employees' future behaviour. Therefore, in organizations, OBM is a plan for managing the behaviour of employees through a formal system of feedback and reinforcement (Johns et al., 1992; Kane and Lawler, 2009).

\subsection{Management by Objectives (MBO)}

Douglas McGregor thought that instead of creating antagonisms because of judgments, the superior should work with subordinates to set goals. This would allow subordinates to exercise self-control and manage their job performance. This supports the original idea of Peter Drucker over the concept of Management By Objectives (MBO). $\mathrm{MBO}$ is more than an appraisal exercise. It is regarded as a philosophy of managerial practice, a method by which managers and subordinates plan, organize, control, communicate, and debate over organizational objectives and how to achieve them. MBO also relates to a system in which people at each level of the enterprise set goals in a process that flows from top to bottom, so that employees at all levels are contributing to the organization's overall goals; and these goals becoming the standards for evaluating each employee's performance (Drucker, 2009; Grote, 2000; McLeod, 1997; Smith et al., 1996).

\subsection{Structure of Performance Appraisal}

In order to provide useful information or feedback to their subordinates, organizations can use both formal and informal performance appraisals. A formal appraisal is conducted at a set time during the year and it is based on performance targets or standards that were set well in advance. The beauty of formal performance appraisal is that employees are assessed based on defined targets. It is also based on organizational policy. Most specifically, formal performance appraisals supply both the employers and employees with valuable information even though employees or subordinates usually require feedback about their future on a more frequent basis. This agitation has given rise to what is now known as informal performance appraisal. Informal performance appraisal is an unscheduled appraisal which represents organizational effort to bridge the developmental gaps that could be created by the traditional formal appraisal system (Mayer, 2001).

\section{Research Methodology}

The quantitative and qualitative techniques of the exploratory research design were used for the study. The study population comprised of the people in Nigeria. The judgmental sampling method was used to select the sample of the study. The sample size of 109 was determined through the sample ratio concept. A researcher-designed questionnaire titled Appraisal Report Questionnaire (ARQ) based on a 5-point Likert-type scale was used to collect both quantitative and qualitative information from primary and secondary sources, while top executives in some selected organizations were interviewed. Secondary data are information collected from books, journals, websites, manuals, newspapers, and other relevant sources. Data collected were organized, verified, sorted and coded in readiness for analysis. Data were analyzed through descriptive and correlation statistical techniques. The mean cutoff point for the analysis of responses was set at 3 points, while the correlation analysis was done using the Statistical Package for the Social Sciences (SPSS) and the result summarized, and presented in figures and tables (Osuala, 2007).

\section{Presentation of Result}

Table-1. Profile of Respondents ( $\mathrm{n}=109$ )

\begin{tabular}{l|l|l|l|l}
\hline S/N & Description & Category & Total & Percentage \\
\hline i & Gender & a) Female & 40 & 36.70 \\
& & b) Male & 69 & 63.30 \\
\hline ii & Education & a) Certificates & 30 & 27.52 \\
& & b) Diplomas & 35 & 32.11 \\
& & c) Degrees & 44 & 40.37 \\
\hline iii & Age & a) $18-30$ years & 25 & 22.94 \\
& & b) $31-50$ years & 45 & 41.28 \\
& & c) $51-70$ years & 39 & 35.78 \\
\hline iv & Experience & a) Below 10 years & 20 & 18.35 \\
& & b) $11-20$ years & 50 & 45.87 \\
& & c) 21 - 35 years & 39 & 35.78 \\
\hline v & Status & a) Low & 15 & 13.76 \\
& & b) Middle & 38 & 34.86 \\
& & c) High & 56 & 51.38 \\
\hline
\end{tabular}


Business, Management and Economics Research

Table-2. Analysis of Frequency and Mean for Responses to Research Questions

\begin{tabular}{|c|c|c|c|c|c|c|c|c|c|c|c|}
\hline \multirow[t]{3}{*}{$\mathbf{S} / \mathbf{N}$} & \multirow{3}{*}{$\begin{array}{l}\text { Restatement of Research } \\
\text { Questions }\end{array}$} & \multicolumn{5}{|c|}{ Scores } & \multirow{3}{*}{$\begin{array}{l}\text { Row } \\
\text { scores }\end{array}$} & \multirow{3}{*}{$\begin{array}{l}\text { Sampl } \\
\text { e size }\end{array}$} & \multirow{3}{*}{$\begin{array}{l}\text { Mean } \\
\text { score }\end{array}$} & \multirow{3}{*}{$\begin{array}{l}\text { Decision - } \\
\text { @ } 3 \text { points }\end{array}$} & \multirow{3}{*}{$\begin{array}{l}\text { Grand } \\
\text { mean }\end{array}$} \\
\hline & & SA & $\mathbf{A}$ & $\mathbf{N}$ & D & SD & & & & & \\
\hline & & 5 & 4 & 3 & 2 & 1 & & & & & \\
\hline$\overline{\mathrm{i}}$ & $\begin{array}{l}\text { Performance appraisal helps } \\
\text { in compensation management }\end{array}$ & 50 & 40 & 1 & 3 & 15 & 434 & 109 & 3.98 & True & \multirow[t]{6}{*}{3.79} \\
\hline ii & $\begin{array}{l}\text { Feedback is not part of } \\
\text { performance appraisal }\end{array}$ & 10 & 5 & 2 & 3 & 89 & 174 & 109 & 1.60 & False & \\
\hline iii & $\begin{array}{l}\text { Performance appraisal } \\
\text { contributes to management } \\
\text { decision-making }\end{array}$ & 65 & 30 & 2 & 2 & 10 & 465 & 109 & 4.27 & True & \\
\hline iv & $\begin{array}{l}\text { Performance appraisal is a } \\
\text { motivational tool }\end{array}$ & 55 & 35 & 1 & 4 & 14 & 440 & 109 & 4.04 & True & \\
\hline $\mathrm{v}$ & $\begin{array}{l}\text { Employee productivity is } \\
\text { crucial to organizational } \\
\text { management }\end{array}$ & 60 & 45 & 2 & 1 & 1 & 489 & 109 & 4.49 & True & \\
\hline vi & $\begin{array}{l}\text { Employees in charitable } \\
\text { organizations are not properly } \\
\text { appraised }\end{array}$ & 58 & 42 & 3 & 2 & 4 & 475 & 109 & 4.36 & True & \\
\hline
\end{tabular}

CORRELATION

/VARIABLES $=$ PA EP

$/$ PRINT=ONETAIL NOSIG

/STATISTICS DESCRIPTIVE

/MISSING=PAIRWISE

\section{Correlations}

[DataSet0]

Table-3. Descriptive Statistics

\begin{tabular}{l|l|l|l}
\hline & Mean & Std. Deviation & $\mathbf{N}$ \\
\hline Performance & -.43038 & .497711 & 6 \\
\hline appraisal & 4.35 & 3.461 & 6 \\
\hline
\end{tabular}

Table-4. Correlations

\begin{tabular}{l|l|l|l}
\hline \multicolumn{2}{l}{} & Perf-App & Employ.Prod. \\
\hline Perf. App. & Pearson Correlation & 1 & $.790^{*}$ \\
\hline & Sig. (1-tailed) & & .028 \\
\hline & $\mathrm{N}$ & 6 & 6 \\
\hline Employee Prod. & Pearson Correlation & $.790^{*}$ & 1 \\
\hline & Sig. (1-tailed) & .028 & \\
\hline & $\mathrm{N}$ & 6 & 6 \\
\hline
\end{tabular}

* Correlation is significant at the 0.05 level (1-tailed).

\subsection{Discussion}

Performance appraisal is increasingly gaining attention in governments, business and charitable organizations because of the rapidly changing work values and the need for competitiveness in the changing global economic system. As shown in the conceptual framework of this study, in figure 1, performance appraisal helps in feedback development, compensation management, management decision making, employee motivation, and leading to employees' productivity. The major use of performance appraisal is to judge the effectiveness of employees, managers and overall organizational performance. In addition, employees desire feedback and how well they are performing their duties, because they are often sad if kept in the dark as to their performance ratings. The three major purposes of performance appraisal include; administrative, informative, and motivational purposes. When used administratively, appraisals provide an objective basis for promotions, salary increases, transfers, and separations, for very weak performers or those who have reached their career plateau. As a source of information, both management and the employee will learn the extent of performance and the strengths and weaknesses prevailing. And as a motivational tool, appraisals create a learning experience that encourages employees to improve on their performance. The profile of respondents in table 1, showed that they were qualified to make meaningful contributions to the academic potency of the study. As in table 2, they were sure that performance appraisal helps in quality compensation management. This supports Akanwa (1997) that performance evaluation is used to regulate employees pay. It was denied that feedback is not part of performance appraisal. This response agrees with Armstrong (2004) that feedback is necessary to boost employee morale and performance. Also the study participants agreed that performance appraisal contributes to management decision-making. According to Ivancevich (2001) performance evaluation is used in making important decisions that affect employees and organizational performance. They equally, agreed that performance appraisal is a motivational mechanism for improved employee productivity (Feldman, 2007). It was asserted that employees' productivity is crucial to management. This agrees with the 
previous findings of Barltrop and McNaughton (1997) that employees' motivation and productivity represent the cornerstone of sound management. A critical revelation is that employees in charitable organizations in Nigeria are not being properly appraised against the fact that performance appraisal leads to improved employee productivity. This is a matter that requires urgent attention in the research community to enhance the chances of improved productivity in the competitive economic, social, political and cultural environments. Even though conducting a less subjective and a more objective performance appraisal is not always easy, it must nevertheless, be done so as to encourage performance feedback, employees' motivation, management decision-making, as well as other relevant measures to promote organizational productivity. In recognition of this status, Torrington et al. (2005) postulate that appraising performance is not a precise measurement, but often, a subjective exercise. It has a long history of being damned for its ineffectiveness and at the same time being anxiously sought for by employees wanting to know how they are doing. They insist that performance appraisal is difficult to do, and frequently done badly with some serious results, but on the rare occasions when it is done well it can be invaluable for the business, government, and literally life transforming for the employees. Performance appraisal is therefore, probably, the most demanding and skillful management activity and is dreaded by both appraisers' and appraisees'. In table 4, the correlation analysis was used to determine the level of relationship between the variables of interest. In correlation analysis $\mathrm{R}$, is the coefficient of correlation of the model. In this study, therefore, $\mathrm{R}=790$ means that there is strong positive correlation between the dependent and independent variables used in the model, and also that there is strong positive relationship between performance appraisal and employees productivity. This is the interest of the study. This result supports the earlier report of Gomez-Mejia et al. (2004) that performance appraisal is important for performance improvement which is critical to achieving improved and sustained performance levels of employees and their organizations.

\subsection{Scope for Further Study}

In view of changing work values, further study should examine the relationship between subjective appraisals and poor employees' productivity in government beaureacracy. This is necessary to seek for solution against this problem.

\subsection{Recommendations}

i. Because of the importance of performance appraisal in organizations it has to carefully, review the employee's strengths and weaknesses against the requirements of envisaged future higher level responsibilities and make recommendations to management for decision-making.

ii. It is essential that the appraiser must comment on the evaluation made and also the appraisee should be allowed to verify, and agree or disagree, with the appraisal as a measure of checking the problems of subjective appraisal.

iii. Regulatory agencies for private and public organizations should step up oversight functions over issues of performance appraisal in privately-owned-small-enterprises (POSEs) and charitable organizations where performance appraisal is not fully in vogue. The bogus argument of free enterprise mentality or non-forprofit (NFP) perspectives is not enough to stop people at work from realizing their fullest potential or selfactualization.

iv. Feedback on performance should always be provided to employees both as a means of behaviour modification and for performance improvement.

v. When standards of performance are set, employees should be allowed to use their initiative to realize them. This encourages self-control that fascinates employees of today.

\section{Conclusion}

The continued success and growth of an organization depends on its ability and capacity to select, develop, assess, and retain the number and quality of employees it needs to meet its strategic objectives. An effective performance appraisal system is one of the measures that an organization employs to attain goals. The use of performance appraisal has become increasingly necessary because it is not easy, if not impossible, to give or assess the quality of an individual employee without proper evaluation. The basic assessments of paper qualification, experience, character, personality are things that must be taken into consideration by employers so as to record and note the calibre of their individual employees. Research reports have shown that the behaviour of employees contributes significantly to the level of their output in organizations. As every organization pays its workers for their performance, it is imperative to compare what workers should do as evident from the performance standards with what they have actually done. Performance appraisal therefore, is an important management activity and technique for managerial effectiveness. 109 respondents participated in the study conducted through the exploratory research design, and the result showed strong positive correlation between performance appraisal and employees productivity.

\section{Acknowledgements}

The author likes to acknowledge Dr. Nancy Wairimu, Mwema and Dr. Heizel Gachoka Gachunga, both of Jomo Kenyatta University of Agriculture and Technology, Kenya, for their work on Performance Appraisal and Employee Productivity in Organizations, which helped to inspire this investigation.

\section{Conflict of Interest}

This author declares no conflict of interest in respect of the authorship and/or the publication of this paper. 


\section{Funding}

There is no funding or research grant from any institution or agency in respect of the authorship or publication of the paper.

\section{Author Contribution}

John Nkeobunna Nnah Ugoani, collected, analyzed and interpreted data in respect of this paper. The paper is the intellectual property of the sole author who is therefore, solely, responsible for any omissions or liabilities arising there from.

\section{Originality}

Human productivity is crucial for performance and research continues to explore ways of enhancing it through quality evaluations. At the present time few reports look at appraisal dilemmas of employees in charitable organizations. This is one of the new studies in recent years beaming a torchlight to close knowledge gaps.

\section{References}

Akanwa, P. U. (1997). Fundamentals of human resource management in Nigeria. 1st edn: Kosoko Press Ltd: Owerri, Nigeria.

Anderson, G. C. (1993). Managing performance appraisal systems. Blackwell: Oxford.

Anseel, F., Beatty, A. S., Shen, W., Lievens, F. and Sacket, P. R. (2015). How we are doing after 30 years? A metaanalytic review of the antecedents and outcomes of feedback-seeking behaviour. Journal of Management, 41(1): 318-48.

Armstrong, M. (2004). 360-degree feedback. In M. Amstrong (ed) a handbook of human resource management. 9th edn: New Delhi: Kogan Page India: 513-21.

Barltrop, C. J. and McNaughton, D. (1997). Measures of Staffing Efficiency. Banking Institutions in Developing Markets: Interpreting Financial Statements. and D. McNaughton C. J. Barltrop, eds. The World Bank: Washington, D. C. 7-21.

Bernichon, T., Cook, K. E. and Brown, J. D. (2003). Seeking self-esteem and specific self-views. Journal of Personal and Social Psychology, 84(1): 194-204.

Drucker, P. F. (2009). The effective executive. Harper-Collins: New York, NY.

Exley, M. (2000). First class coach. Management Today. 96.

Feldman, R. S. (2007). Motivation and Emotion, Psychology. R. S. Feldman (ed). 6th edn: Tata McGraw-Hill Publishing Company Limited: New Delhi, India. 286-318.

Fletcher, C. (2004). Appraisal and feedback. Making performance review work. 3rd ednLondon.

Gomez-Mejia, L. R., Balkin, D. B. and Cardy, R. L. (2004). Appraising and managing performance. Managing human resources. D. B. Balkin L. R. Gomez-Mejia, and R. L. 4th edn: Prentice Hall of India Private Limited: New Delhi. 221-57.

Goodge, P. and Watts, P. (2000). How to manage 360-degree feedback. People Management: 50-2.

Grote, D. (2000). Performance appraisal reappraised. Harvard Business Review, 78(1): 21.

Heller, R. (1998). Motivating people dorling kindersley. London.

Hernandez, D. (2002). Local government performance measurement. Public Management, 84: 10-11.

Holbrook, R. L. J. (2002). Contact points and flash points: Conceptualizing the use of justice mechanisms in the performance appraisal interview. Human Resource Management Review, 12(1): 101-23.

Huet-Cox, G. O., Nelso, T. M. and Sundstorm, E. (1999). Get the most from 360-degree feedback: Put it on the internet. HR Magazine. 91-103.

Ivancevich, J. M. (2001). Performance evaluation and management. J. M. Ivancevich (ed). 8th edn: Human Resource Management, McGraw-Hill Irwin: Boston. 243-65. http://www.mhhe.com/ivancevich.HRM

Johns, G., Xie, J. L. and Fang, Y. (1992). Mediating and moderating effects in job design. Journal of Management, 18(4): 657-76.

Jones, G. R. and George, J. M. (2003). Contemporary management. 3rd edn: Me Graw-Hill: NY, USA.

Kane, J. S. and Lawler, E. E. (2009). Performance Appraisal Effectiveness: Its assessment and determinants. B. M. Stew (ed). JAI Press: Greenwich, LT. 425-78.

Leisink, P. and Knies, E. (2017). Public personnel reforms and public sector HRM in Europe. Utrecht University. http://www.researchsat.net/publications/321370089

Lindsey, J. A. (2005). Performance evaluation: A management basic for librarians. Oxyx. Press: Phoenix, AZ.

London, M. (1997). Job feedback: Living, seeking, and using feedback for performance improvement. Lawrence Erbaum Associates: Mahwah, NJ.

Longenecker, C. O. (1997). Neglected at the top: Executives talk about executive appraisal. Sloan Management Review, 29(2): 41-7.

Mathis, R. L. and Jackson, J. H. (1994). Human resource management. 7th edn: West Publishing Corporation: N.Y, USA.

Mayer, H. H. (2001). A solution to the performance appraisal feedback Enigma. Academy of Management Executive, 5(1): 68-76. 
McGregor, L. (2010). Improving the quality and speed of decision-making. Journal of Change Management, 2(4): 344-56.

McLeod, R. J. (1997). The management of change. Business Studies Review, 3(2): 1-7.

Milkovich, G. T. and Boudreau, J. W. (1997). Performance. G. T. Milkovich and J. W. Boudreau (eds). 8th ednIRWIN Boston. 99-137.

Mwema, N. W. and Gachunga, H. G. (2014). The influence of performance appraisal on employee productivity in organizations: A case study of selected who offices in east Africa. International Journal of Social Sciences and Entrepreneurship, 1(11): 1-13.

Noe, R. A., Hollenbeck, J. R., Gerhart, B. and Wright, P. M. (2004). Managing employees' performance. J. R. Hollenbeck R. A Noe, B. Gerhart, and P. M. Wright (eds). McGraw-Hill, IRWIN: Boston. 238-72.

Osuala, E. C. (2007). Introduction to research methodology. 3rd edn: African-First Publishers, Plc (Africana Academic Books): Onitsha, Nigeria.

Redman, T., Snape, E., Thompson, D. and Kaching, Y. F. (2000). Performance appraisal in the National Health Service. Human Resource Management Journal, 10(1): 1-16.

Rowe, C. (1995). Introducing 360-degree feedback: The benefits and pitfalls. Executive Development. 14-20.

Smith, B. N., Hornsby, J. S. and Shirmeyer, R. (1996). Current trends in performance appraisal: An examination of managerial practice. Sam Advanced Management Journal: 10-15. Available: https://www.semanticscholar.org/paper/Current-Trends-in-Performance-Appraisal\%3A-An-of-SmithHornsby/f247243656c082895a60c5c8f396f0ff0ad0f6be

Stevenson, W. J. (2002). Competitiveness, strategy and productivity. (ed.) W. J. Stevenson. 7th edn: McGraw-Hill, IRWIN: USA. 37-66.

Torrington, D., Hall, L. and Taylor, S. (2005). The appraisal interview. L. Hall and S. Taylor D. Torrington. 6th ednPrentice Hall United Kingdom. 335-52.

Udeze, J. O. (2000). Measuring worker's performance-the appraisal exercise. J. O. Udeze edn: Joebest Books: Enugu, Nigeria. 145-65.

Ugoani, J. N. N. (2016). Employee turnover and productivity among small business entities in Nigeria. Independent Journal of Management \& Production, 7(4): 1063-82. Available: http://www.ijmp.jn.br

VandeWalle, D., Genesan, S., Challagalla, G. N. and Brown, S. P. (2000). An Integrated model of feedback seeking behaviour: Disposition, context, and cognition. Journal of Applied Psychology, 85(6): 996-1003.

Waldersee, R. and Luthans, F. (1994). The impact of positive and corrective feedback on customer service performance. Journal of Organizational Behaviour, 15(1): 83-95.

Wells, R. G. (2002). Guidelines for effective and defensible performance appraisal. Personnel Journal, 61: 776-82.

Werner, J. M. and Bolino, M. C. (1997). Explaining U.S. Court of appeals decisions involving performance appraisal: Accuracy, fairness and validation. Personnel Psychology, 50: 1-24. Available: https://www.growkudos.com/publications/10.1111\%25252Fj.1744-6570.1997.tb00898.x/reader

Whitaker, B. G., Dahling, J. J. and Levy, P. (2007). The development of a feedback environment and role-clarity model of job performance. Journal of Management, 33(4): 570-91.

Wilson, J. P. and Western, S. (2001). Performance appraisal: An obstacle to training and development? Career Development International, 6(2): 92-102.

Zhang, X. and Bartol, K. M. (2010). Linking empowering leadership and employee creativity: The influence of psychological empowerment, intrinsic motivation, and creative process engagement. Academy of Management Journal, 53(1): 107-28.

Zhang, X., Qian, J., Wang, B., Jin, Z., Wang, J. and Wang, Y. (2017). Leaders' behaviours matter: The role of delegation in promoting employees' feedback seeking behaviour. Frontiers in Psychology, 8(920): 1-10. 